\title{
The comparison of Marital Satisfaction in OCD- pateints and normal individuals
}

\section{Sajiad Almardani Some' ${ }^{1}{ }^{1}$}

1-M.A in psychology, Psychology and Educational Sciences, University of Mohaghegh Ardabili, Ardabil, Iran. ORCID: 0000-0002-2973-2745 Email: s_a_s139@yahoo.com

Received: 23/08/2018 Accepted: 23/12/2018

\begin{abstract}
Introduction: Obsessive Compulsive Disorder, creates challenge for both patients and their family system and affected several areas of life.

Aim: The purpose of this study was to the comparison of marital satisfaction in OCD-pateints and normal individuals.

Method: It is a case-control study. The statistical society of the study includes all the patients with OCD Tabriz Razi Hospital formed. 25 patients using simple random sampling as people with OCD and Among Ordinary people as well as the number of 25 people that has been matched and as compared to the Group were selected. After the completed questionnaires, researcher collected them for further analysis, and the data were analyzed using T test.

Results: The results showed that there is significant difference between marital satisfaction in people with obsessive compulsive disorder and normal individuals $(t=2 / 24 ; p=0 / 02)$; this means that marital satisfaction scores in people with OCD is less than normal individuals.

Conclusion: here are People with obsessive compulsive disorder the rate of marital satisfaction lower. These results can have contributions to for planning appropriate treatment for these patients.
\end{abstract}

Keywords: Obsessive Compulsive Disorder, Quality of life, Marital Satisfaction

How to cite this article : Almardani Some'eh, S. (2019). The comparison of Marital Satisfaction in OCD- pateints and normal individuals. Shenakht Journal of Psychology and Psychiatry. 2019; 5 (6): 13-23 .URL :http://shenakht.muk.ac.ir/article-1-355-fa.pdf

Copyright ( 2018 the Author (s). Published by Kurdistan University of Medical Sciences. This is an open access article distributed under the terms of the Creative Commons Attribution-Non Commercial License 4.0 (CCBY-NC), where it is permissible to download, share, remix, transform, and buildup the work provided it is properly cited. The work cannot be used commercially without permission from the journal. 


\title{
مقايسه رضامندى زناشويى در افر اد مبتلا به اختلال وسواس فكرى - عملى و عادى
}

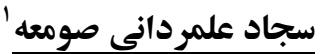

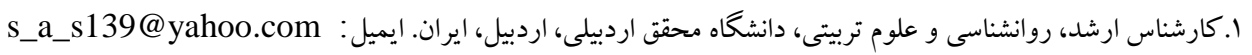

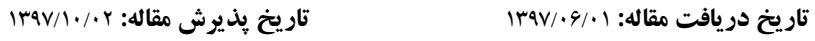

جكيده:

مقدمه: اختلال وسواس فكرى_عملى، جالش جدى هم براى خود بيماران و هم سيستم خانو ادكى ايجاد مى كند و حوزههاى مختلفى

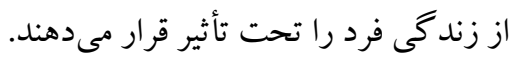

هدف: هدف اين يزوهش، مقايسه رضامندى زناشويى در افراد مبتلا به اختلال وسواس فكرى_عملى و عادى بود. روش: روش اين بزوهش على_مقايسهاى است. جامعه آمارى اين بزوهش را كليه بيماران مبتلا به وسواس فكرى-عملى شهر تبريز، در

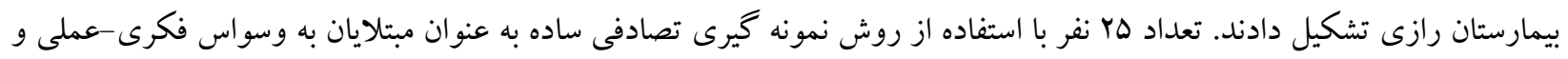

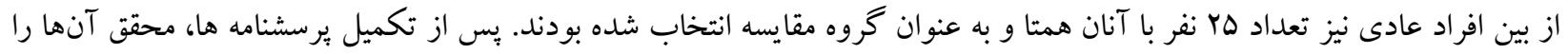
براى بررسى و تحليل بيشتر جمع آورى كرد و دادهاى جمع آورىشده نيز با استفاده از آزمون T مستقل تحليل شد. يافته ها: نتايج بزوهش نشان داد كه تفاوت معنىدارى بين ميزان رضايتمندى زناشويى در افر اد مبتلا به اختلال وسواس فكرى-عملى

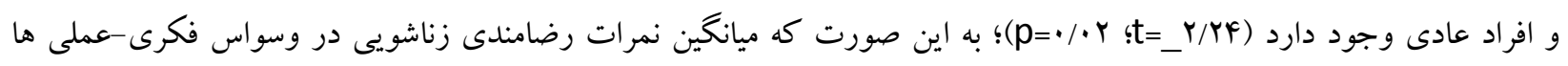
كمتر از افراد عادى بود.

نتيجه كيرى: افراد مبتلا به اختلال وسواس ميزان رضايتمندى زناشويى كمترى دارند. اين نتايج مىتواند تلويحاتى براى برنامهريزىهاى مناسب در جهت درمان اين بيماران داشته باشد. كليد وازه ها: اختلال وسواس فكرى_عملى، كيفيت زندگى، رضامندى زناشويى 


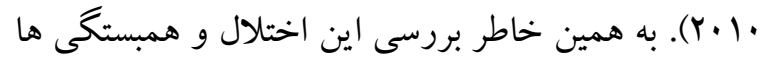
و تأثيراتى كه ممكن است بر ديخر كار كردهاى انسان در مقدمه طول حياتش داشته باشد، مهم به نظر مىرسد.

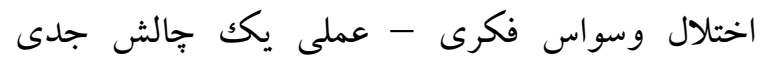
طولانى مدت هم براى خود بيماران و هم سيستم

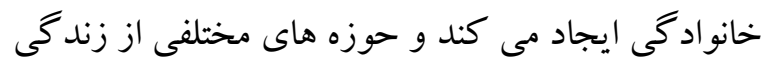
فرد را تحت تأثير قرار مىدهند؛ يكى از اين حوزه ها، رضامندى زناشويى "' و تأثيرات آن بر شخص و خرانواده آن است. رضايتمندى زناشويى را به عنوان درجه اى كه فرد در رابطه ى زناشويى خود به نيازها، انتظارات و تمايلاتش دست بيدا مى كند، مى داند يا رضايتمندى زناشويى، احساس عينى از خشنودى، رضايت و و لذت تجربهشده توسط زن و يا مرد است، وقتى

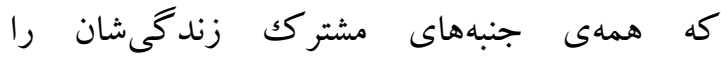
فراكيرد (اليس "، همهئ 1919).

شواهد بزوهشى متعددى حاكى از تأثير منفى اختلال وسواس فكرى - عملى بر رضايتمندى زناشويى است

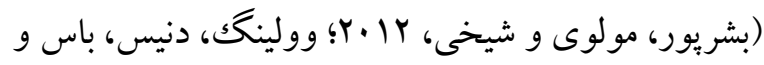

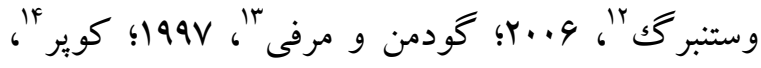

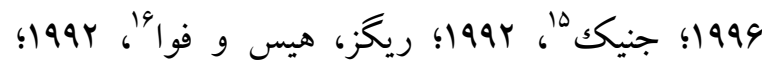
املكمبٍ، دهان و هو گديون"، ، 199 و لوينگستون،

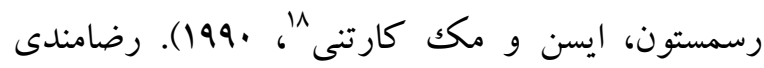
زناشويى گرايش و هيجان مثبت نسبت به همسر يا شوهر

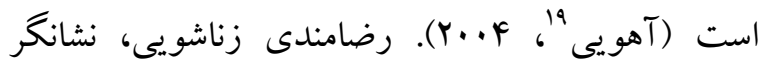
استحكام و كارايى نظام خانواده است و جنانجه به خاطر

\footnotetext{
${ }^{10}$. Marital satisfaction

${ }^{11}$. Ellis

12. Vulink, Denys, Bus \& Westenberg

${ }^{13}$. Goodman \& Murphy

${ }^{14}$. Cooper

15. Jenike

16. Riggs, Hiss \& Foa

${ }^{17}$. Emmelkamp, deHaan \& Hoogduin

${ }_{18}^{18}$. Livingston, Rasmussen, Eisen \& McCartney

${ }^{19}$. Ahuyi
}

اختلال وسواس فكرى- عملى ' يك بيمارى مزمن و ناتوان كننده است كه داراى دو جنبه ى شناختى (فكرى) و رفتارى (عملى) است (آبراموويتز، ديكون، اولتنجى،

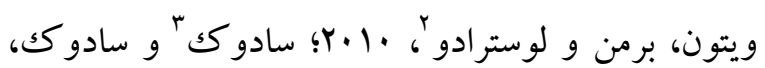

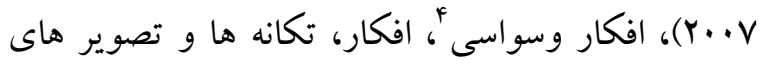

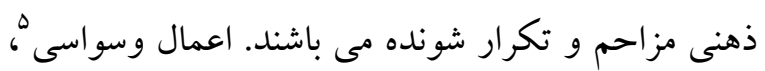
رفتار خودآكاه ميزان شده و تكرارى نظير شمارش يا اجتناب مىباشند. فكر وسواسى موجب اضطراب شخص مى گردد درحالى كه انجام عمل وسواسى اضطراب شخص را كاهش مىدهد (كايلان و و سادوكى، r...r) و اختلال روانى متداولى است كه با ميزان شيوع طول عمر تخمينى تقريباً r-r درصد، شيوع آن دو برابر شيوع اسكيزوفرنيا و اختلال دو قطبى است (ساسون، زوهار،

$$
\text { جايرا، لاستيگك، آى ان سو و هندلر ل، 199V). }
$$
تا همين اواخر اختلال وسواس فكرى-عملى، اختلال نه جندان شايع كه بيش آگهى ضعيفى به درمان دارد، در

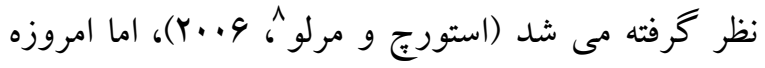
اختلال وسواس فكرى-عملى در رديف جهارم شايعترين اختلالهاى روانيزشكى قرار كرفته است (سادوكى و و

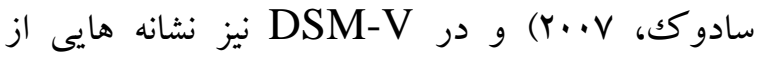
ناهمگ طبقهبندىهاى اختلال وسواس فكرى- عملى است

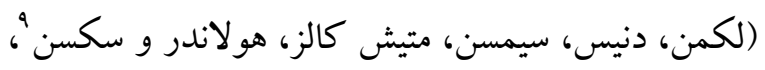

\footnotetext{
1. Obsessive Compulsive Disorder(OCD)

2. Abramowitz, Deacon, Olatunji, Wheaton, Berman \& Lostardo

${ }^{3}$. Sadock

4. Obsessions

5 . Compulsions

${ }^{6}$. Coplan

7 . Sasson, Zohar, Chopra, Lustig, Iancu \& Hendler

${ }^{8}$. Storch \& Merlo

9 . Leckman, Denys, Simpson, Mataix-Cols, Hollander \& Saxena
} 
شواهد موجود نشان مى دهند اختلال وسواس فكرى -

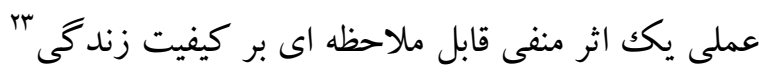

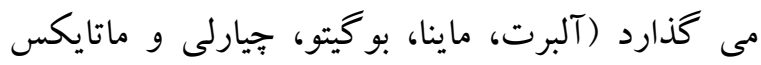

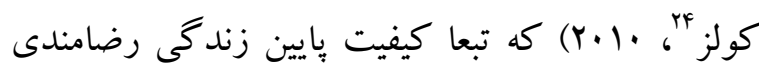

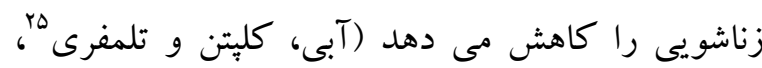

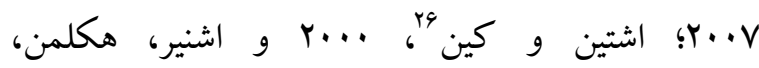

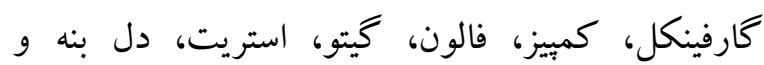

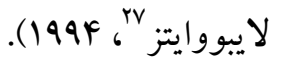
در حال حاضر، بررسى بيشينه هاى موجود نشان مى دهد كه رضايت زناشويى در مبتلايان به اختلال وسواس فكرى-عملى و افراد عادى متفاوت است و بين آنها ارتباط وجود دارد و با توجه به اهميت آن در كاركرد خانواده، يى بردن به عوامل مؤثر در بيشبينى و بهبود و بالا بردن رضامندى زناشويى، حائز اهميت است و با بـائ

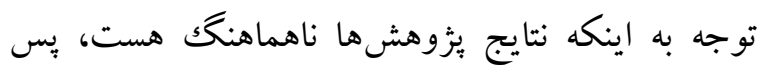
سؤال اصلى بثزوهش، اين است كه آيا بين دو گروه افراد

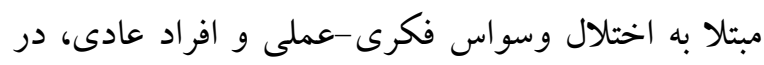
متغير رضامندى زناشويى تفاوت معنادارى وجود دارد يا

روش يزٔوهش حاضر على - مقايسه اى از نوع مورد شاهدى است. با توجه به قانون حداقل حجم نمونه در تحقيقات على - مقايسه ای كه براى هر گروه ها نفر ذكر

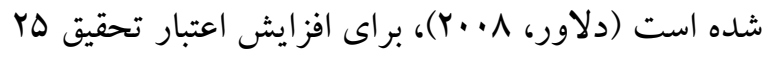
نفر براى هر كروه به عنوان نمونه انتخاب شد. از بين

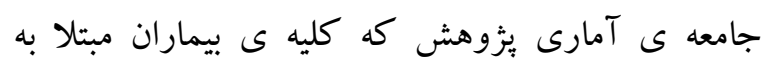

${ }^{23}$. quality of life

24. Albert, Maina, Bogetto, Chiarle \&MataixCols

25. Abbey, Clopton \& tlumphrey

${ }^{26}$. Stein \& Kean

${ }^{27}$. Schneier, Heckleman, Garfinkel, Campeas, Fallon, Gitow,

Street, Del Bene \& Liebowitz
مشكلات جسمى و يا روانى (مانند وسواس)، رضامندى زناشويى كمترى باشد، استحكام و دوام خانواده دهار تزلزل خو اهد شد و بيامدهاى منفى به دنبال خو اهد داشت

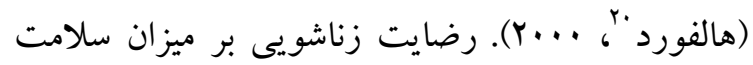
روانى، جسمانى، رضايت از زندگى، موفقيت در شغل و ارتباطات اجتماعى مؤثر بوده و يكى از مهمترين شاخصهاى رضايت از زندكى است (بيرامى، فهيمى،

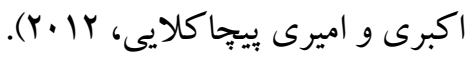

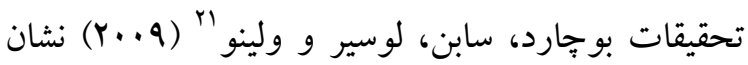
داد كه هيجان هاى مثبت و خود ابرازى عامل هايى هستند كه باعث مىشوند رضامندى زناشويى در بين افراد بالا رود و به دليل اينكه افراد داراى اختلال وسواس فكرىعملى نمىتواند اين عوامل را آشكار سازند، دهّار مشكلات زناشويى مى شوند و رضامندى زناشويىشان بشدت كاهش مى يابد. بعلاوه يزوهش مختارى، بهر امى، باداش، حسينيان و سلطانى زاده (Y/Y) نشان داد كه شخصيت هاى وسواسى در زندگى زناشويى، رضامندى كمى دارند و هر جهه نشانه هاى وسواسى بهبود يافت، رضامندى زناشويى افراد افزايش يافت.

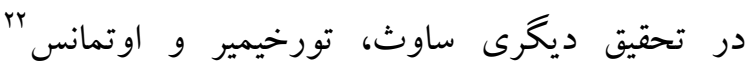
(Y..人) وسواس را هم شامل مىشود) و رضامندى زناشويى رابطه معنادارى وجود دارد؛ بدين صورت كه هرجه رضايت زناشويى افزايش مى يابد، نشانه هاى وسواس رو به كاهش است. همجينين در بثزوهش ديخرى بين رضامندى زناشويى با كيفيت زندگى و مهارت زندگى همبستخى مثبت و با گرايش به وسواسى همبستخى منفى معنادارى

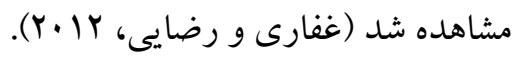

\footnotetext{
20 . Halford

${ }^{21}$. Bouchard, Sabounn, Lussier \& Villeneuve

${ }^{22}$. South, Turkheimer \& Oltmanns
} 
و جهار نمرهى فرعى به دست آورد. بنا بر كفته راكمان و

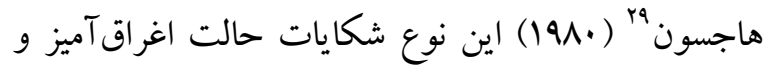

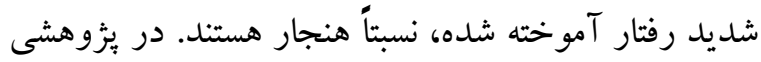
با · f بيمار نشان دادند كه نمره كل اين بيرسشنامه نسبت به تغييرات درمانى حساس است؛ در كل ثابت شده است كه برسشنامه ى وسواسى مادسلى ابراز مناسبى براى

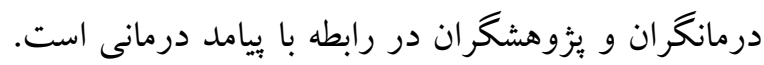
همجنين اين برسشنامه وسيلهى خوبى براى بررسى سببشناسى سير و بيش آكهى انواع مختلف شكايتهاى وسواسى است. ضريب پايايى با روش باز آزمايى ه9/.

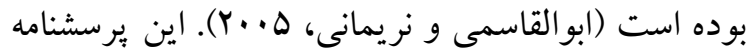
به زبان فارسى ترجمه و اعتبار و پايايى آن تائيد شده

$$
\text { است (قاسم زاده و مجتبايى، هـ • (Y). }
$$

يرسشنامه رضامنلى زناشويح: اين برسشنامه از هال سؤال و r إمقياس تشكيل شده است كه شامل ابعاد موضوعات شخصيتى، ارتباطات، حل تعارض، مسائل مالى، اوقات فراغت، روابط جنسى، ترتيب فرزند، ارتباط با خانواده اصلى و دوستان، نقشهاى همسرى و جهت گيرى مذهبى و معنوى است. السون و همكاران اعتبار اين

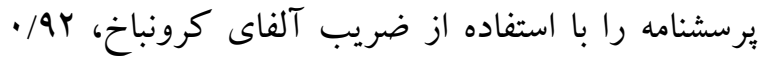
كزارش كرده اند. با توجه به طولانى بودن سؤالات اين مقياس، فرم هاى متعددى از آن استخراج شده است.

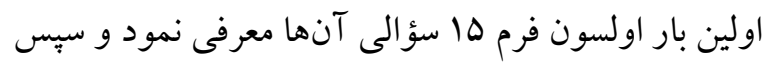

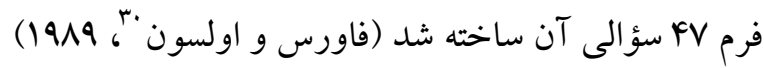
در همين اواخر فرم ها سؤالى اين يرسشنامه نيز ساخته

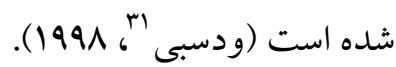

\footnotetext{
29. Rachman \& Hodgston

30. Foweres \& Olson

31. Wadsby
}

اختلال وسواس فكرى - عملى شهر تبريز را در بيمارستان رازى شامل مى شود، به حجم هr نفر با استفاده از روش تصادفى ساده (از بين كسانى كه توسط روانيزشك يا روانشناس تشخيص اختلال وسواس فكرى- عملى به آنها داده مىشود) به عنوان مبتلايان به اختلال وسواس فكرى - عملى انتخاب شد و از بين افراد عادى نيز تعداد

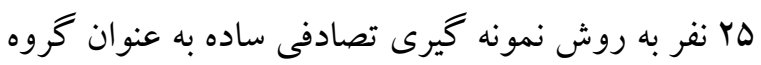
مقايسه انتخاب كرديد.

ابزار مصاحبه بالينى: بر اساس مصاحبهى بالينى ساختار يافته

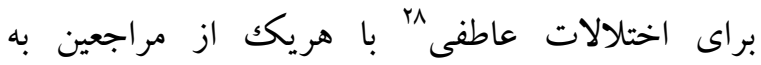
بيمارستان رازى، توسط روانيزشكان و روانشناسان با بـان بران توجه به ملاككهاى تشخيصى DSM-IV-TR بود. يرسشنامه وسواس فكرى- عملى مادسلى: يرسشنامه وسواس فكرى و عملى مادسلى توسط هاجسون و راكمان (199V) بهمنظور ئزوهش در مورد نوع و حيطهى

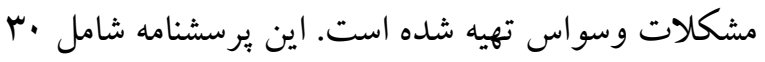
ماده است كه نيمى از آنها با كليد درست و نيمى با كليد غلط هست. اين برسشنامه در اعتبار يابى اوليه در بيمارستان مادسلى توانسته است •له بيمار وسواسى را از •ه بيمار رواننزند به خوبى تفكيك نمايد. همجنين اين

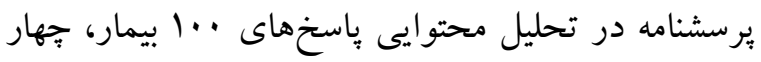
مؤلفهى عمده را كه منعكس كنندهى جهار نوع مشكل وسواسى در بيماران بود، مشخص نمود. اين جهار مؤلفه عبارتاند از: وارسى، تميزى، كندى و شك وسواسى كه جهار مقياس فرعى را تشكيل مىدهند. با استفاده از يك روش نمره گذارى ساده مىتوان يك نمرهى وسواس كلى رلى

\footnotetext{
${ }^{28}$. Stractural Interview for Affective Disorders
} 
رضامندى زناشويى را به نمونه هايى داد كه توسط روانيزشك يا روانشناس تشخيص اختلال وسواس فكرى_عملى داده شده اند. همجينين از نمونه هاى عادى كه از جامعه ى همتا شده از نظر اقتصادى و فرهنگى با جامعه ى مورد بثزوهش ما بودند، نيز درخواست تكميل

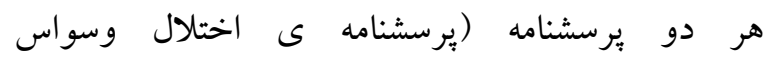
فكرى_عملى و رضامندى زناشويى) شد. داده هاى جمع آورى شده با استفاده از آزمون T مستقل تحليل شد و جهت تحليل آنها از نرم افزار آمارى SPSS IV استفاده

شل.

\section{يافته ها}

تعداد هr نفر بيمار مبتلا به اختلال وسواس فكرى-عملى هلى و هr نفر افراد عادى و بهنجار با ميانگين (انحراف معيار) سنى Tr/GY M (Y/Y) در اين \&ئوهش شركت داشتند. جدول ا ميانخين و انحراف استاندارد نمرات آزمون رضامندى زناشويى را در بيماران مبتلابه اختلال وسواس فكرى-عملى و افراد عادى را در گروههاى مورد مطالعه نشان مى دهد.

جدول شمارهى ا ويزگى هاى جمعيت شناختى و تحليل نتايج به دست آمده از تى تست (T) را نشان مى دهد.
در بيزوهش حاضر از فرم كو تاه اين برسشنامه استفاده شد كه از FV آيتم تشكيل شده است. اين آزمون توسط

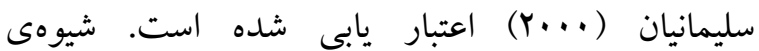
نمره كذارى اين برسشنامه به روش ليكرت است كه به هر كزينه از ا تا ه نمره داده مى شود. سليمانيان دربارهى اعتبار اين يرسشنامه مىنويسد كه سؤالات به رؤيت متخصصان روانشناسى رسانده شد و روايى صورى يرسشنامه مورد تأييد قرار گرفت. در مرحله بعد اين

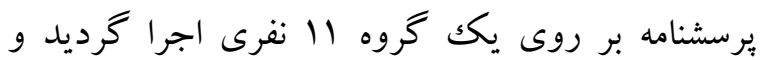
ضريب يايايى آن از طريق آلفاى كرونباخ ه9/• به دست آمد. در يثزوهشى، اعتبار اين آزمون با استفاده از ضريب همبستكى بيرسون و با روش بازآزمايى (به فاصله يك آك

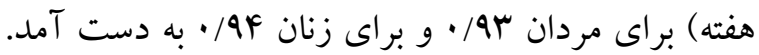
همجنين ضريب همبستخى اين وبرسشنامه با مقياس رضايت خانوادكى از |q/. تا ه191. و با مقياس رضايت

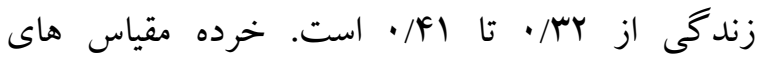
يرسشنامه اينريج زوج هاى ساز گار و ناساز گار را متمايز

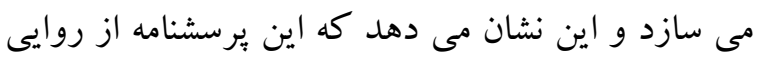
ملاكك خوبى برخوردار است (عامرى، V....

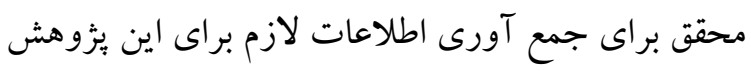
بعد از اخذ مجوزهاى لازم براى استفاده از بيماران بيمارستان رازى، به بيمارستان مراجعه و برسشنامه ى

جدول ا. ميانكين، انحراف استاندارد و نتايج آزمون t تست متغير رضامندى زناشويى افراد مبتلا به اختلال وسواس و افراد عادى

\begin{tabular}{|c|c|c|c|c|c|}
\hline P(سطح معنادارى) & $\mathbf{T}$ & انحراف استاندارد & ميانكين & كروه & شاخص \\
\hline$\%$ rq & $-Y / Y Y$ & $10 / 99$ & $\mid r r / 91$ & افراد مبتلا به OCD & زناشويى \\
\hline
\end{tabular}

است. همجنين با توجه به مقدار t 1 محاسبه شده، (t=-Y/YFF $(\mathrm{p}<\cdot / \cdot \Delta)$ هץ+•
همان طور كه در جدول 1 ملاحظه مى شود، ميانكين آزمون رضامندى زناشويى، در افراد مبتلا به اختلال

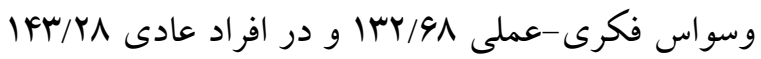


رضايى (Y (Y))؛ بشريور، مولوى و شيخى، (Y) (Y)؛

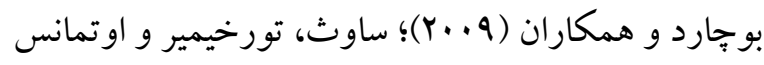
(Y..人)

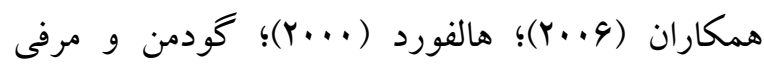

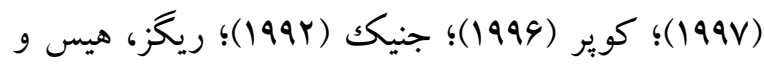

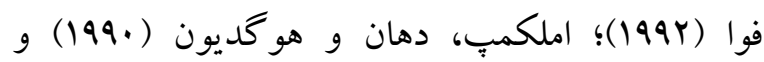
لوينگستون و همكاران ( •199) همسو و همخوانى دارد كه معتقدند افرادى كه به نوعى دهار اختلال وسواس فكرى-عملى هستند، به مرور زمان از رضامندى

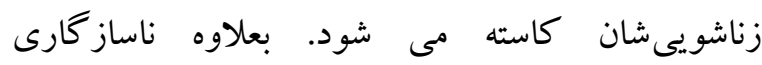
زناشويى هاب، ناكامى، فشارهاى مالى و اقتصادى از جمله ييامدهاى متداول استرسى هستند كه اين اختلال بر بيماران و اعضاى خانوادهى آنها به بار مى آوردد

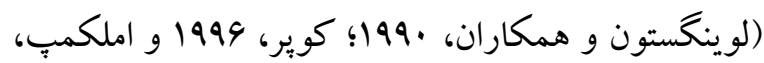
دهان و هو كديون، .1999). نتايج تحقيقات محققان به تأثير منفى اختلال وسواس بر رضايتمندى زناشويى اشاره

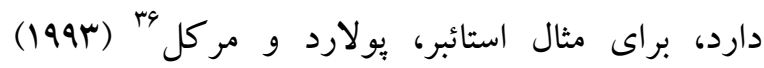

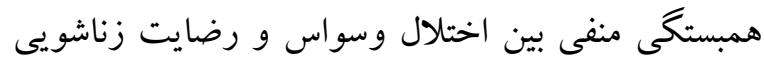

$$
\text { را گز ارش نمودند. }
$$

جنين نتيجه اى طبق نظر عمرانى فرد، آكوجاكيان،

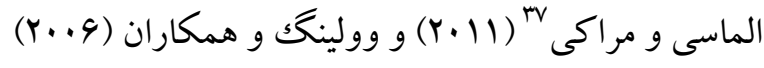
دال بر اين است كه وسواس فكرى-عملى مىتواند در رضايت زناشويى بيمار تأثير بحذارد و بيماران وسواسى نسبت به مبتلايان به ساير اختلالات نوروتيك و كروه

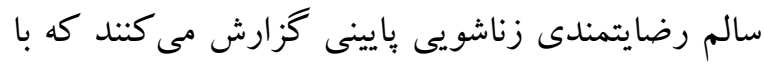
شيوه هاى مداخله ى شناختى رفتارى مى توان رضايت

$$
\text { زناشويى را بهبود بخشيد. }
$$

35. Marital discord

36. Staebler, Pollard \& Merkel

37. Omranifard, Akuchakian, Almasi \& Maraci
نمىشود. به عبارت ديخر تفاوت معنادارى در مورد رضامندى زناشويى در دو گروه مبتلا به اختلال وسواس فكرى-عملى و افراد عادى وجود دارد (q (p=/p). به اين ترتيب كه ميانگين گروه مبتلا به اختلال وسواس فكرى - عملى در مؤلفهى رضامندى زناشويى يايين تر از كروه مقايسه و عادى است و اين نشان مى دهد كه دهى مبتلايان به وسواس، رضامندى زناشويى بايينى دارند.

خانواده به عنوان يك سيستم كاركردهايى دارد كه بر اساس مدل مكك مستر شامل حل مسئله، ارتباطات، نقش ها، : باسخگ رفتارى است. هدف يُزوهش حاضر، مقايسه ى رضامندى زناشويى در افراد مبتلا به اختلال وسواس فكرى-عملى و عادى بود. نتايج بزوهش نشان داد كه بين دو گروه مبتلا به اختلال وسواس فكرى- عملى و افراد عادى و بهنجار از نظر رضامندى زناشويى تفاوت معنادارى وجود دارد؛ به اين صورت كه ميانگين نمرات رضامندى زناشويى در اختلال وسواس فكرى-عملى ها كمتر از افراد عادى بود. يافته هاى يُزوهش حاضر و نيز بثزوهش هاى قبلى نشان مى دهد كه اختلال وسواس فكرى-عملى با نقص در برخى از اين كاركردهاى خانواده همراه است كه از آن

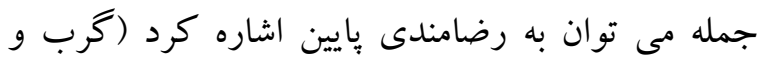

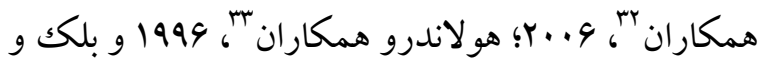

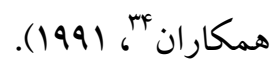
همجِين يافتهى اين يُزوهش طور كاملاً مستقيم با نتايج يثزوهشهاى مختارى و همكاران (Y.Y.Y)؛ غفرى و

\footnotetext{
${ }^{32}$. Grabe, Ruhrmann, Ettelt, Buhtz, Hochrein \& SchulzeRauschenbach

${ }^{33}$. Hollander, Kwon, Stein, Broatch, Rowland \& Himelein

${ }^{34}$. Black, Gaffney, Schlosser \& Gabel
} 
در آن جزء عوامل زمينه ساز اختلال وسواس فكرىعملى به شمار ميايد، آموزش هاى لازم به خانواده هاى مستعد ارائه گردد. به عنوان مثال در جهت ارتقاى نحوه ى رابطه برقرار كردن در خانواده مى توان از آموزش مهارت هاى ارتباطى استفاده كرد. همجِنين براى درمان اين افراد بهتر است از خانو اده درمانى استفاده شود.

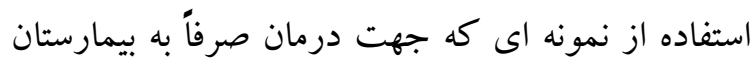
روانيزشكى رازى تبريز مراجعه كرده بودند، استفاده از مطالعهى مقطعى و ناتوانى در كنترل برخى متغيرهاى مزاحم (اختلال هاى همبود) محدوديت هاى عمده ى مطالعه ى حاضر بودند. همجنين بعضى از اعضا (بيمار مبتلا به وسواس)، در هنگام انجام تحقيق دارو مصرف مى بـ كردند كه اين ممكن است بر شرايط هيجانى آنها تأثير مثبت يا منفى كاذب داشته باشد كه اين عوامل كنترل نشد. نتايج اين مطالعه به فرايند شناسايى افراد در تشخيص و درمان اختلال وسواس از طريق توجه به شاخص رضامندى زناشويى كمكك مى كند. بديهى است كه كام اول موفقيت در اين برنامه، شناخت عميق افراد مبتلا به اختلال وسواس فكرى - عملى و مؤلفه هايى كه مرتبط با اختلال آنهاست تا با برنامهريزى صحيح و بهره گيرى از توان مشاورهاى روانشناسان و ايجاد فضاى حمايتى (اجتماعى و روانى) براى آنها، سعى شود كه محيط هايى فراهم شود كه بتوان در اين محيط اهداف خود را بيخيرى كرد كه اين نكته در مورد احياى هر دو متغير وابستهى بثزوهش مسئله مهمى است؛ بنابراين با تأكيد بر اهميت نقش اين عوامل و ضرورت ايجاد زمينهاى بيشتر حمايت اجتماعى از اين بيماران، لزوم اجراى تحقيقات

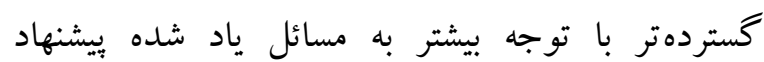

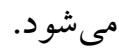

شواهد مقدماتى به دست آملده از بزّوهش ها نشان مى دهد كه افراد وسواسى عموماً بيكار بوده و موقعيت اجتماعى و اقتصادى بايينتر و موقعيت زناشويى آشفته اى دارند كه مى تواند به همه ى ابعاد شناختى فرد ضربه وارد كند و علاوه بر آن، فرد رادر برابر ديخر اختلال ها آسيب پِير تر مى گرداند (ايسن، مانسبو، بينتو، كولز،

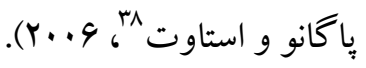

\section{نتيجه كيرى} به طور كلى مى توان كفت از آنجا كه بر اساس اغلب

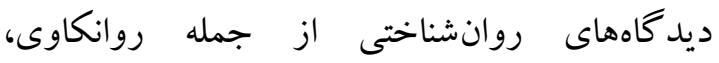
رفتار گرايى، شناخت گرايى، انسان كرايى و اخيراً به طور جدى بوم نخرها، خانواده و رضامندى زناشويى بين والدين و به تبع روابط درست بين اعضا مهم ترين و بيشترين نقش را در تكوين شخصيت اعضاى خود و در بديد آيى اختلالات روانى دارد، ضرورى مىنمايد كه در صدد حفظ سلامت ساختار و كاركرد خانواده بود كه به تبع با حفظ سلامت آن، رضامندى زناشويى مدنظر ما نيز حاصل مى شود. كليد مداخله موفق در مورد رفتارهاى عضو بيمار كمك كردن به خانواده براى حل كار آمدتر و مؤثرتر تضادهاى مرتبط با نشانه هاى وسواسى است. به اين ترتيب خانواده كاركردهاى حل

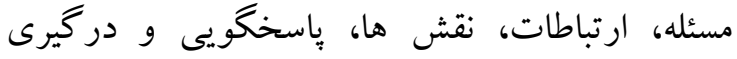
عاطفى و نيز كنترل رفتارى خود را بهبود مى بخشد. بنابراين بهتر است علاوه بر درمان بيماران وسواسى،

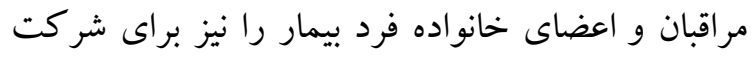
در برنامه هاى آموزشى مرتبط، تشويق كرد. همجنين بهتر است در جهت بهبود ساز كارى زناشويى كه اختلال

\footnotetext{
${ }^{38}$. Eisen, Mancebo, Pinto, Coles, Pagano \& Stout
} 
Beirami, M., Fahimi, S., Akbari, E., Amiri Pichakolaei, A. (2012). Prediction of Marital Satisfaction Based on Attachment Styles and Differentiation Components, Journal of Basic Principles of Mental Health, 14 (1), 64-77. (In Persian)

Black DW, Gaffney G, Schlosser S, Gabel J. (19981). The impact of obsessive compulsive disorder on the family: Preliminary findings. Journal Nerv Mntl; 86: 440-2.

Bouchard, S., Sabounn, S., Lussier, Y,. Villeneuve, E. (2009). Relationship quality and stability in couples when one partner suffers from borderline personality disorder. Journal of marital and family therapy.35(4).446-456.

Cooper, M. (1996). Obsessive-compulsive disorder. effects on family members. American Journal of Orthopsychiatry, 66, 296-304.

Delavar, A. (2008). Research Method in Psychology and Educational Sciences, Tehran: Virayesh Publishing. (In Persian)

Eisen J.L., Mancebo, M.A., Pinto, A., Coles, M.E., Pagano, M.E., Stout, R. \& et al.(2006). Impact of obsessive-compulsive disorder on quality of life. Comprehensive Psychiatry, 47,270-275.

Ellis, A. (1986). Ratoinal - emotive therapy applied to relationship therapy. Joumal of Ratoinal Emotive Therapy. 6,pp.67-76.

Emmelkamp,P. M. G., deHaan, E., \& Hoogduin, C. A. L. (1990). Marital adjustment and OCD. British Joumal of Psychiatry, 156, 55-60.

Foweres BJ, Olson DH .(1989). ENRICH martial inventory. A discriminant validity and cross validation assessment. Journal of Marital and Family Therapy; 15:65-79.

Ghaffari, M., Rezaei, A. (2012). The Relationship between marital satisfaction and quality of life with the obsessive and lifestyle skills of married students of Payam Noor University, Journal of Medical Sciences, Islamic Azad University, 72, 140. (In Persian)

Ghassemzadeh, H., Mojtabai, R., etal. (2005). Psychometric Properties of a Persian Language Version of Bdi- II. Depression \& Anxiety, 21, 185-192.

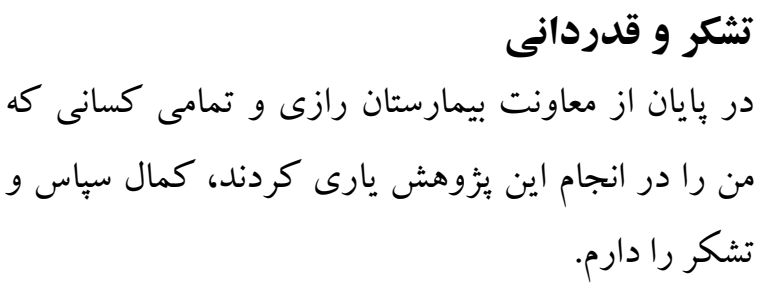

\section{References}

Abbey, R.D., Clopton, J.R., tlumphrey, JD. (2007). Obsessive-Compulsive Disorder and Romantic Functioning. Department of psychology, Texas Teach University, Lubbock, TX 7940-20 51 USA. Therapy, 40 (2007), pp. 825-838.

Abolqasemi, A., Narimani, M. (2005). Psychological tests. Ardebil: Rezvan Garden Publishing. (In Persian)

Abramowitz, J. S., Deacon, B. J., Olatunji, B. O., Wheaton, M. G., Berman, N. C., Lostardo, D., et al. (2010). Assessment of obsessivecompulsive symptom dimensions: Development and evaluation of the dimensional obsessive- compulsive scale. Psychological Assessment, 22, 180-198.

Ahuyi, S. (2004). Study of relation of business stress and marital consent in male teachers. (Master's thesis, University of Roudehen).

Albert U, Maina G, Bogetto F, Chiarle A, MataixCols D. (2010). Clinical predictors of health-related quality of life in obsessive-compulsive disorder. Compr Psychiatry, 51(2), 193-200.

Ameri, F. (2007). The Effect of Strategic Family Therapy Interventions in Marital Disorders. $\mathrm{PhD}$ thesis. Tarbiat Modares University. (In Persian)

Basharpour, S., Molavi, P., Sheikhi, S. (2012). Comparison of Marital Satisfaction and Quality of Life in Patients with ObsessiveCompulsive Disorder with Patients with Other Anxiety Disorders and Healthy Individuals, Urmia Journal of Medical Sciences, 23, 6, 597-605.(In Persian) 
Goodman,W. K., \& Murphy, T. (1997). Obsessive compulsive disorder and Tourette's syndrome. In: S. Enn, \& J. Coyle (Eds.), Pharmacological management of neurological and psychiatric disorders. New York: McGraw-Hill.

Grabe HJ, Ruhrmann S, Ettelt S, Buhtz F, Hochrein A, Schulze- Rauschenbach S, et al. (2006) Familiarity of obsessive-compulsive disorder in nonclinical and clinical subjects. Am J Psychiatry; 163: 1986-92.

Halford, W.K. (2000). Brief therapy for couples: Helping partners help themselves. Brisbane City: Griffith University.

Hollander E, Kwon JH, Stein DJ, Broatch J, Rowland CT, Himelein CA. (1996). Obsessive compulsive and spectrum disorders: overview and quality of life issues. J Clin Psychiatry; 57: $3-6$.

Jenike, M. A. (1992). Pharmacologic treatment of obsessive compulsive disorder. Psychiatric Clinics of North America, 15, 895-919.

Kaplan, J., Saduk, B. (2003). Psychoanalysis Behavioral Sciences. Translation by Nusratallah Pourafkari. Tabriz, Shahrab Publishing. (In Persian)

Leckman, J. F., Denys, D., Simpson, H. B., MataixCols, D., Hollander, E., Saxena, S., et al. (2010). Obsessive-compulsive disorder. A review of the diagnostic criteria and possible subtypes and dimensional specifiers for DSMV.Depression and Anxiety, 27, 507-527.

Livingston-Van Noppen, B., Rasmussen, S., Eisen, J., \& McCartney, L. (1990). Family function and treatment in obsessive compulsive disorder. In: M. Jenike, L. Baer,W. Minichello (Eds.), Obsessive compulsive disorder. theory and management (2nd ed. pp. 325-340). Chicago: Yearbook Medical Publishers.

Mokhtari, S., Bahrami, F., Padash, Z, Hoseinian, S., Soltanizadeh, M. (2012). The Effect of Schema Therapy on marital satisfaction of couples with Obsessive-compulsive personality disorder (OCPD). Interdisciplinary Journal of Contemporary Research in Business, 12(3), 207-225.
Omranifard V., Akuchakian S., Almasi A., Maraci M.R. (2011). Effect of religious cognitivebehavior therapy on religious content obsessive compulsive disorder and marital satisfaction؛ European Psychiatry؛ Volume 26, Supplement 1, 1742.

Rachman, S., \& Hodgston, R. J. (Eds.). (1980). Obsessions and Compulsions. Englewood Cliffs,7, Prentice-Hall.

Riggs, David S., Hiss, Hella., Foa, Edna B., (1992). Marital distress and the treatment of Obsessive Compulsive Disorder, Behavior Therapy, Volume 23, Issue 4, Pages 585-597.

Sadock BJ, Sadock VA. (2007). Kaplan and Sadock's synopsis of psychiatry: Behavioral sciences/ clinical psychiatry.10th ed. Philadelphia: Lippincott Williams and Wilkins; 259.

Sasson, Y., Zohar, J., Chopra, M., Lustig, M., Iancu, I. \& Hendler, T.(1997). Epidemiology of obsessive-compulsive disorder: a world view. Joumal Clin Psychiatry, 58, (12), 7-10.

Schneier, F. R., Heckleman, L. R., Garfinkel, R., Campeas, R., Fallon, B. A., Gitow, A., Street, L., Del Bene, D., \& Liebowitz, M. R. (1994). Functional impaiment in Social Phobia. Joumal of Clinical Psychiatry, 55, 322-331.

Soleimanian, A. (2000). Investigating the Impact of Irrational Thoughts on Marital Neglegation. Graduate degree. Tehran Teacher Training University. (In Persian)

South, S. C., Turkheimer, Eric. \& Oltmanns, Thomas F. (2008). "Personality disorder symptom and marital functioning". Joumal of Consulting and Psychology. 76 (5). 769.

Staebler, C.R., Pollard, C.A., Merkel, W.T.,(1993). Sexual history and quality of current relationships in patients with obsessive compulsive disorder: a comparison with two other psychiatric samples. J. Sex Marital Ther. 19, 147-153.

Stein, M. B., \& Kean, Y. M. (2000). Disability and quality of life in Social Phobia: epidemiologic findings. American Joumal of Psychiatry, 157, 1606-1613.

Storch, E.A., Merlo, L.J. (2006). Obsessive-compulsive Disorder. Strategies for Using $\mathrm{CBt}$ and 
Pharmacotherapy. The Joumal of Family Practice, 55, 329-333.

Vulink, N. C.C., Denys, D., Bus, L. \& Westenberg, H.G.M. (2006). Sexual pleasure in women with obsessive-compulsive disorder, Journal of Affective Disorders, 91, 19-25.

Wadsby, M. (1998). Evaluation of the Swedish version of the ENRICH Marital Inventory. Nordic Joumal of Psychiatry, 52 (5), 379-388. 